\title{
PENETRATION OF BOG PEATS AND LAKE SEDIMENTS BY TRITIUM FROM ATMOSPHERIC FALLOUT ${ }^{1}$
}

\author{
Eville Gorham and Ronald H. Hofstetter ${ }^{2}$ \\ Botany Department, University of Minnesota, Minneapolis, Minnesota
}

\begin{abstract}
Tritium in surface bog peats of the Red Lake wetland, northern Minnesota, exhibits about the same concentration as in atmospheric precipitation, which is still appreciably enriched by tritium from nuclear weapon testing. Past input pulses are not preserved in the peat profile, and the pattern of subsurface decline suggests that most of the modern precipitation rich in tritium is removed rapidly by evapotranspiration and by lateral runoff within the top $1.5 \mathrm{~m}$ of the $3.5-\mathrm{m}$ thickness of little-decomposed Sphagnum peat at the crest of the raised bog. However, some bomb tritium has penetrated, presumably by molecular diffusion, down to the discontinuity between the highly permeable Sphagnum peat and the underlying well-decomposed and much less permeable fen peat. In profundal lake sediments of four Minnesota lakes the influence of highly enriched precipitation from the early 1960's has likewise been largely transitory and of major significance only in sediment depths of less than $1 \mathrm{~m}$, although some penetration below that depth has occurred, presumably by molecular diffusion.
\end{abstract}

\section{INTRODUCTION}

Owing to atmospheric testing of nuclear weapons, concentrations of tritium in atmospheric precipitation rose sharply in the early 1960's (International Atomic Energy Agency 1967). Peak levels were commonly observed in late spring or early summer, and in 1963 they ranged between 3,000 and 7,000 tritium units (T.U. $)^{3}$ in mid-continental North America (Fig. 1). Over the next 4 years these seasonal peaks declined steadily, and since 1967 they have reached only a few hundred T.U. Because of these phenomena, it seemed possible that the high levels of tritium in precipitation might provide valuable information on how deeply and rapidly such precipitation penetrated peats and lake sediments. This study was undertaken, therefore, to investigate whether past input pulses had been preserved in peat and sediment profiles.

\section{Sites AND Methods}

Peat samples were collected from the great wetland complex north of Upper Red Lake in Minnesota (Heinselman 1963, Finney and Farnham 1968, Hofstetter 1969), mainly from deep peats in a raised bog dominated by the bog moss (Sphagnum spp.) and black spruce (Picea mariana). Cores of lake sediment were collected from the deepest parts of four lakes in the forested part of Minnesota: Elk Lake $\left(47^{\circ} 11^{\prime} \mathrm{N}, 95^{\circ} 13^{\prime} \mathrm{W}\right)$ and Deming Lake $\left(47^{\circ} 10^{\prime} \mathrm{N}, 95^{\circ} 10^{\prime} \mathrm{W}\right)$ in Itasca State Park, Clear-

${ }^{1}$ Contribution No. 98 from the Limnological Research Center, University of Minnesota, Minneapolis, Minn. (Manuscript received April 24, 1971; accepted June 28, 1971.)

${ }^{2}$ Present address: Biology Department, University of Miami, Coral Gables, Florida 33124.

${ }^{3}$ One tritium unit $=1$ atom of tritium per $10^{18}$ atoms of hydrogen, or 3.24 picocuries per liter of water. water and Hubbard Co., respectively, in the northwestern part of the State; Christmas Lake $\left(44^{\circ} 54^{\prime} \mathrm{N}\right.$, $93^{\circ} 33^{\prime}$ W), Hennepin Co., a few miles west of Minneapolis; and Lake of the Clouds $\left(48^{\circ} 08^{\prime} \mathrm{N}, 91^{\circ} 08^{\prime}\right.$ W), Lake Co., near the Canadian border in northeastern Minnesota.

A modified Livingstone sampler (Livingstone 1955) was employed to collect long cores of peat or sediment, usually in $50-\mathrm{cm}$ sections. The first short cores of lake sediment were taken with a Jenkin sampler (Mortimer 1942), and the second cores with a lucite tube thrust into the sediment by scuba divers (Elk L.) or on long rods (Christmas L.). Because the Livingstone and Jenkin corers are driven vertically, some degree of downward contamination cannot be avoided. However, in taking the last peat core a back-hoe attached to a large tracked vehicle was used to excavate a pit about $2 \mathrm{~m}$ deep. Peat was then sampled by hand down one side of the pit, taking care to avoid contamination by downward drip, and the corer was then driven into a bench cut on another side of the pit to take deeper samples uncontaminated by the small amounts of drip collecting in the bottom of the pit.

Samples were packed into large polyethylene food containers, which were wrapped with two or three layers of masking tape and refrigerated until they could be shipped away for sample preparation and analysis by Isotopes, Inc. On receipt by the company, each container was emptied rapidly into a roundbottom flask which was then connected to a coldfinger trap. A vacuum line was connected to the trap, the system was pumped down for about $5 \mathrm{~min}$, and the trap was immersed in a slurry of dry ice and trichloroethylene. After sufficient water had been collected it was transferred to a pre-dried glass bottle for analysis by gas counting and, where necessary, electrolytic enrichment. 


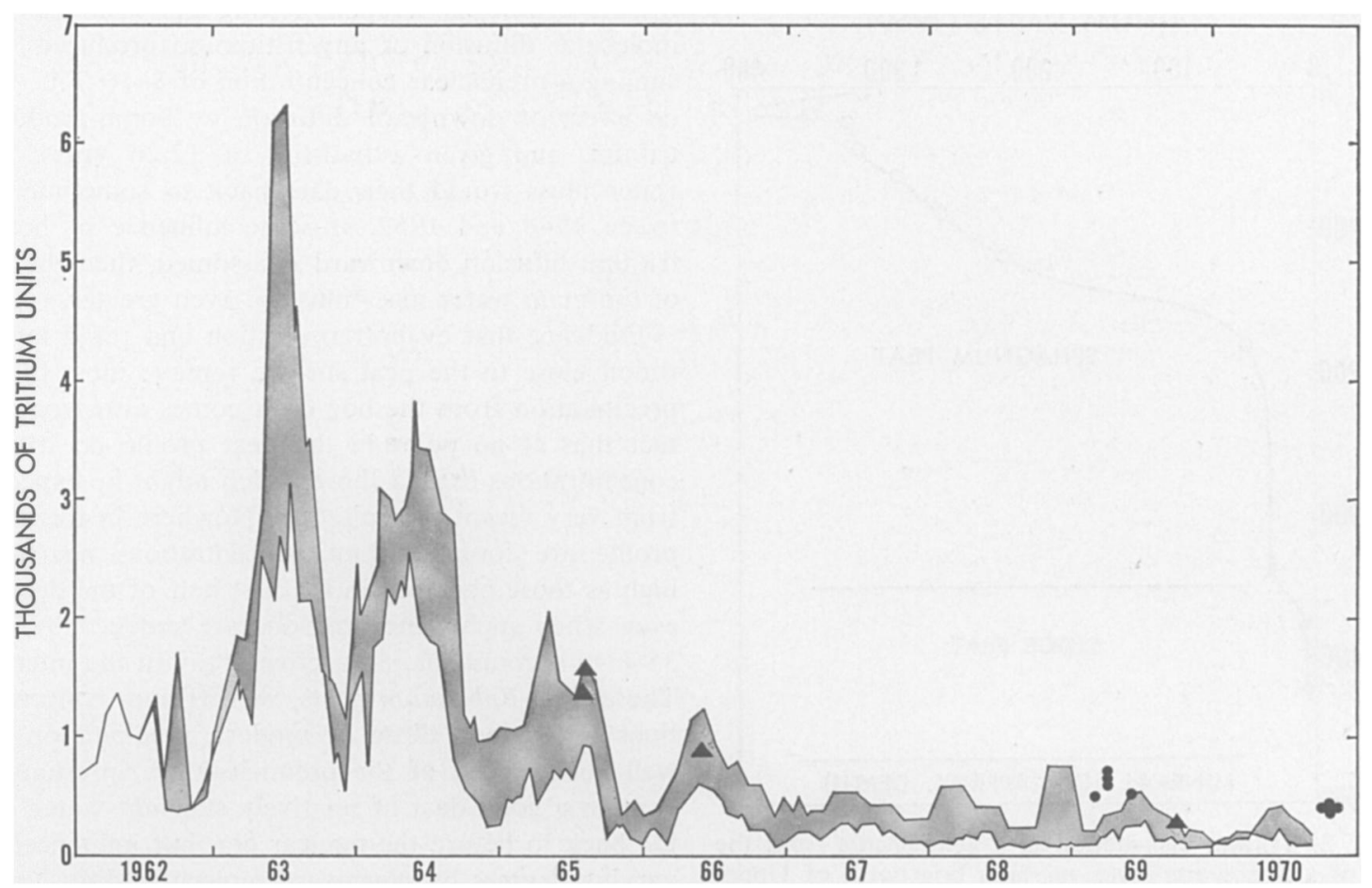

FIG. 1. The range of tritium concentrations in atmospheric precipitation from 1962 to 1970 at four midcontinental stations in North America (Lincoln, Nebraska; Bismarck, North Dakota; Madison, Wisconsin; and Chicago, Illinois). Triangles represent waters from the uppermost peats in Minnesota bogs, and dots represent waters from Minnesota lakes.

\section{Results AND Discussion}

The data of greatest interest are presented in Fig. 1-4. Peats and lake sediments are considered separately.

\section{Interstitial waters of peat deposits}

Samples were collected in July 1965, May 1966, and September 1969. On these occasions the surface tritium levels were within the yearly range of concentration for atmospheric precipitation, as shown in Fig. 1.

In 1965 the surface value in a bog peat profile not far from the nearby sedge fen was $1,386 \pm 30$ T.U., but a core sample from 76 to $114 \mathrm{~cm}$ yielded 693 \pm 30 T.U. and one from 325 to $365 \mathrm{~cm}$ only 11 \pm 0.6 T.U. This last value was only a little above the levels of 8-10 T.U. quoted (Carlston 1964) for atmospheric precipitation in the continental interior of the United States prior to nuclear testing (but neglecting radioactive decay of $50 \%$ every 12.26 years). In 1966 the surface tritium level at another site near the crest of the raised bog was down to $904 \pm 26$ T.U. in little-decomposed Sphagnum bog peat; at $170-190 \mathrm{~cm}$ in the same material the concentration was much lower, $52.9 \pm 1.4$ T.U. In welldecomposed fen peat at $350-380 \mathrm{~cm}$ tritium concentration was only $6.9 \pm 0.3$ T.U., and at $440-470 \mathrm{~cm}$ even lower, $5.1 \pm 0.9$ T.U.
Because little-decomposed Sphagnum peat is quite permeable (Malmström 1923, Boelter 1965, 1969), the seventeenfold difference in tritium concentration between the 1966 surface sample and that at 170$190 \mathrm{~cm}$ seemed rather remarkable. We were led to suspect that precipitation falling upon the raised bog was removed largely by evapotranspiration and by lateral mass flow close to the surface, leaving a relatively stagnant water mass saturating the deeper Sphagnum peat horizons (cf. Odén 1964, Forsgren 1966, two important references which came unfortunately late to our notice). These deeper horizons, however, were penetrated to some degree by tritium from weapons testing, because the concentration of $52.9 \pm 1.4$ T.U. was well above the known levels (8-10 T.U.) of precipitation prior to the nuclear era.

To examine tritium distribution in the peat profile more carefully, samples were taken in 1969 at much closer intervals as shown in Fig. 2, which also represents a site very near the crest of the raised bog. On this occasion the tritium concentration rose from $316 \pm 17$ T.U. at the surface to $388 \pm 18$ T.U. at $18 \mathrm{~cm}$ depth. Presumably the most recent rains were somewhat lower in tritium than those immediately preceding them. Below $18 \mathrm{~cm}$ depth tritium concentrations declined relatively slowly to $218 \pm 13$ T.U. at $120 \mathrm{~cm}$, and then very steeply to $48.2 \pm 3.2$ 


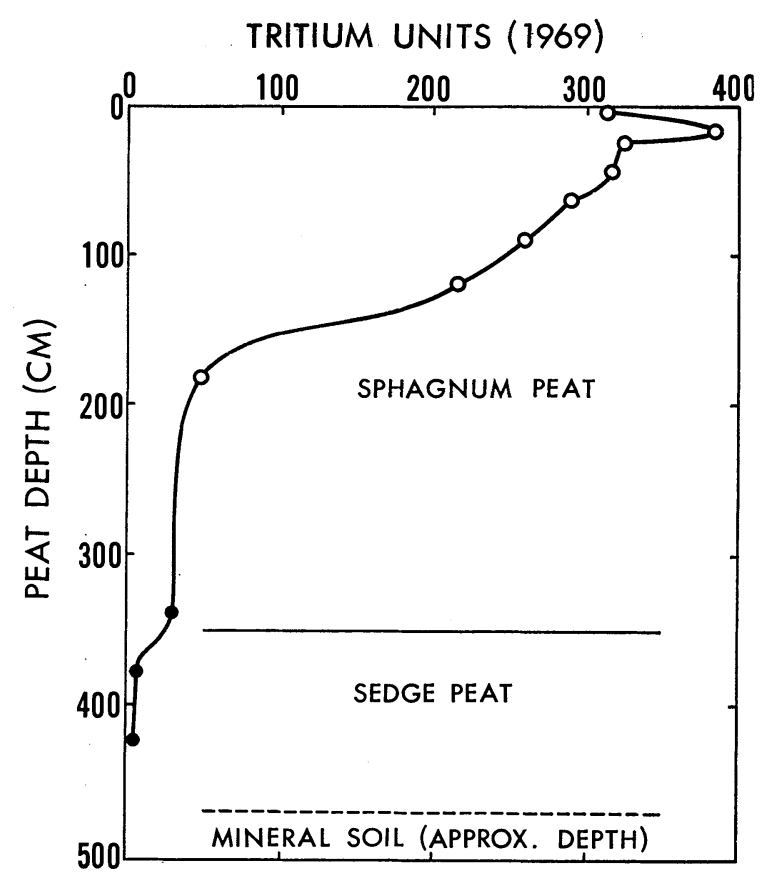

FIg. 2. Tritium distribution in a peat profile from the crest of a Sphagnum-Picea mariana bog north of Upper Red Lake in Minnesota. Circles represent samples from the excavated peat face, dots represent samples taken by Livingstone corer from the excavated pit.

T.U. at $180 \mathrm{~cm}$. Below $180 \mathrm{~cm}$ the decline became very slow, to $29.0 \pm 1.8$ T.U. at $330-350 \mathrm{~cm}$. The pattern of decline with depth shown in Fig. 2 supports very strongly, therefore, the hypothesis that most of the modern precipitation rich in tritium which falls upon the bog crest is removed rapidly by evapotranspiration and by lateral mass flow (runoff) within about the top meter and a half of the Sphagnum peat, which has a thickness at this site of about $3.5 \mathrm{~m}$ and is relatively undecomposed throughout. According to Farnham and Grubich (1966), who examined a site close by the present one, the bulk density of this Sphagnum peat is about $0.06-0.08$ $\mathrm{g} / \mathrm{cc}$. Below the zone of lateral mass flow tritium presumably penetrates the more stagnant mass of peat water chiefly by molecular diffusion.

Beneath the Sphagnum bog peat is a little over a meter of well-decomposed, darker, and much less permeable fen peat, for which Farnham and Grubich (1966) quote a bulk density range of about 0.15$0.25 \mathrm{~g} / \mathrm{cc}$. (They also give a radiocarbon date for the basal Sphagnum peat of 2,250 \pm 120 years before the present.) Across the discontinuity separating bog and fen peat tritium concentration again falls sharply, from $29.0 \pm 1.8$ T.U. at $330-350 \mathrm{~cm}$ to $7.7 \pm 0.6$ T.U. at $350-400 \mathrm{~cm}$. A slower decline is then evident, to $3.0 \pm 0.9$ T.U. at $390-445 \mathrm{~cm}$ near the underlying glacial deposits. Such a low concentration of tritium probably indicates precipitation predating the era of nuclear weapons testing and unaffected by molecular diffusion of any tritium so produced. Assuming a prenuclear concentration of 8-10 T.U. and no effect of downward diffusion by bomb-produced tritium, and given a half-life of 12.26 years, this water mass would then date back to sometime between 1948 and 1952. If some influence of bombtritium diffusion downward is assumed, then the age of the main water mass must be even greater.

Evidence that evapotranspiration and rapid lateral runoff close to the peat surface remove most of the precipitation from the bog crest comes also from the fact that at no point in the peat profile do tritium concentrations exceed those which might be expected from very recent precipitation. Nowhere in the 1969 profile are found tritium concentrations nearly as high as those observed in the first half of the decade, even when such concentrations are reduced by $25-$ $35 \%$ to account for radioactive decay in the interval. The deeper Sphagnum peats, with tritium concentrations lower than those of modern precipitation but well above those of the prenuclear era, presumably contain a good deal of relatively stagnant water dating back to before the nuclear era, but influenced to varying degrees by downward molecular diffusion of bomb tritium.

The results reported here confirm the belief that artesian conditions, sometimes suggested as partly responsible for the elevation of the bog crest, are unlikely to be of any significance. Their existence can of course also be discounted on the basis that such a thick deposit of acid Sphagnum peat could not have developed in the presence of alkaline artesian water rich in calcium.

\section{Interstitial water of lake sediments}

Sediment samples were collected from four lakes in 1969 and 1970. Lake water samples were also collected for comparison. Tritium in the lake water samples of late winter 1969 averaged 600 T.U., whereas those of autumn 1970 averaged 394 T.U. As shown in Fig. 1, these concentrations are distinctly greater than most of those for atmospheric precipitation in the period 1967-70, and particularly those for winter samples, which must make a major contribution to lakes through spring thaw and runoff. Such results are not unexpected, because in this region annual rates of precipitation and evaporation are rather similar. Therefore, replacement of the water mass in a lake may require several years.

In the uppermost $10 \mathrm{~cm}$ of sediment, tritium concentrations were very close to those in the overlying water (Fig. 3 and 4). Beneath the surface sediment in Elk L. and Christmas L. tritium concentrations declined rapidly within the top $50-100 \mathrm{~cm}$. (The decline is probably a little steeper than shown, because a slight degree of downward smearing oc- 


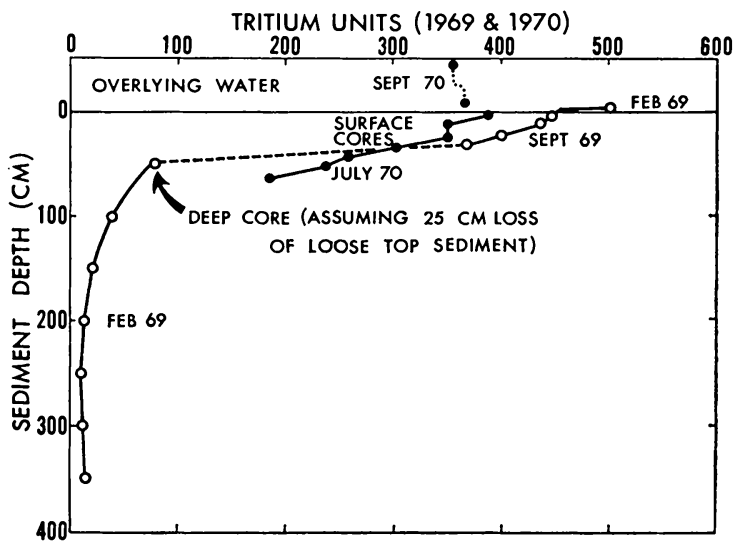

FIG. 3. Tritium distribution in sediment cores from the profundal region in Elk Lake, Clearwater Co., Minnesota.

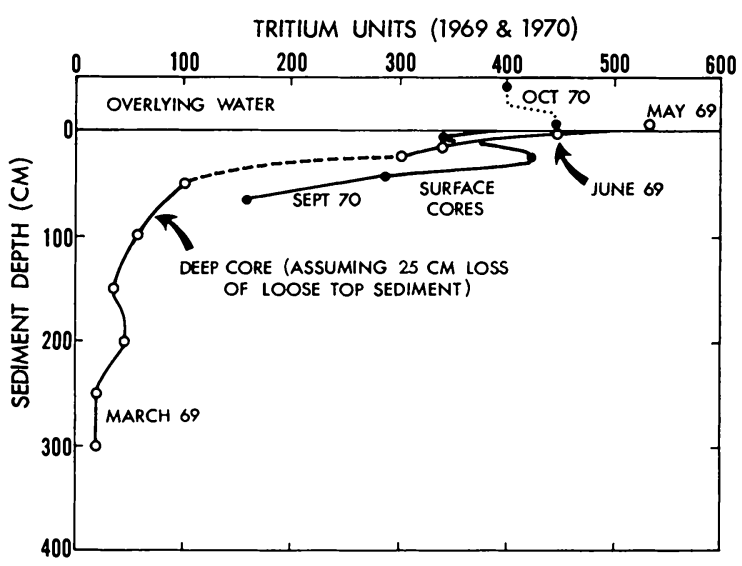

FIG. 4. Tritium distribution in sediment cores from the profundal region in Christmas Lake, Hennepin Co., Minnesota.

curs in the operation of the coring devices.) The subsurface peak at $25 \mathrm{~cm}$ in the second core from Christmas L. presumably reflects in some degree the periodical fluctuations of tritium in atmospheric precipitation.

In 1970 high tritium levels were observed deeper in the shallow sediment cores than in 1969. Although different coring techniques were employed, it seems unlikely that they were responsible for the difference in tritium penetration.

Unfortunately, the short and long cores could not be matched up exactly, because in the latter some of the less dense surface sediment was mixed with overlying water and flowed on opening the tube. We estimate this loss to represent about $25 \mathrm{~cm}$ and have adjusted the depths in Fig. 3 and 4 by this amount.

The initial steep decline lessened below 50-100 $\mathrm{cm}$ and gradually leveled off. In Elk L. tritium leveled off below about $200 \mathrm{~cm}$ at about 10-13 T.U. In Christmas L. tritium declined to 38 T.U. at $150 \mathrm{~cm}$, rose to $50 \mathrm{~T} . \mathrm{U}$. at $200 \mathrm{~cm}$, and then leveled off at
20-21 T.U. between 250 and $300 \mathrm{~cm}$. A long core from Lake of the Clouds showed a decline from 44 T.U. at $50 \mathrm{~cm}$ (adjusted depth) to a minimum of 14 T.U. at $200 \mathrm{~cm}$, below which it fluctuated between 20 and 29 T.U. from 250 to $550 \mathrm{~cm}$. A long core from Deming $\mathrm{L}$. fluctuated even more, ranging from 13 to 59 T.U. between 50 and $1,045 \mathrm{~cm}$. The highest concentration was observed at the bottom of the core and the lowest at $455 \mathrm{~cm}$. At the top of the core (50 $\mathrm{cm}$ adjusted depth) the tritium concentration was 43 T.U.

Although these deep tritium concentrations are above those of prenuclear atmospheric precipitation, it would be unwise to assume such deep penetration of bomb tritium. Operation of the Livingstone corer with casing through the ice involves keeping it in the same hole as much as possible, and this may allow some downward penetration of surface water rich in tritium. Contamination is also possible while the core is being extruded into metal troughs on the lake ice, for although great care was taken, handling in the open in very cold weather is not optimal for avoiding accidental contamination.

For the reasons given above, the concentrations observed in deep cores may be too high and overly variable. However, they do indicate, together with the data from short cores, that lake waters recently enriched in tritium have not moved very far into the sediments by vertical mass flow. Presumably some tritium enters the uppermost few centimeters of sediment owing to turbulent disturbance of the surface layers (Gorham 1958) and the activities of the benthic fauna. Added to this will be some degree of downward molecular diffusion. However, the total absence in interstitial sedimentary waters of tritium concentrations higher than those in current precipitation suggests that the influence of highly enriched precipitation from the early to mid 1960's has been largely transitory and of major significance only in very shallow depths of less than $1 \mathrm{~m}$.

The depth of tritium penetration into the lake sediments is distinctly less than into the bog peats examined earlier. Presumably their fine-grained and somewhat gelatinous texture makes them considerably less permeable than the coarse-grained and porous Sphagnum peats.

\section{AcKnowledgments}

This work was generously supported by grants to the senior author from the Graduate School, University of Minnesota, and the U. S. Atomic Energy Commission (contract AT-11-1-1802), and by a grant from the National Science Foundation (grant GB 3814) to Prof. H. E. Wright, Jr., and the senior author. We are grateful to Professors R. S. Farnham, J. E. Sanger, H. Sjörs, and H. E. Wright, Jr., for assistance with sampling, and to Dr. R. M. Brown (International Atomic Energy Agency, Vienna) and Dr. F. J. Pearson, Jr. (U. S. Geological Survey, Washington) for kindly providing data on tri- 
tium in atmospheric precipitation. Professors R. S. Farn $\rightarrow$ Gorham, E. 1958. Observations on the formation and ham, H. E. Wright, Jr., and G. R. Blake and Dr. F. R. breakdown of the oxidized microzone at the mud surCagle kindly commented on the manuscript. face in lakes. Limnol. Oceanogr. 3: 291-298.

\section{Literature Cited}

Boelter, D. H. 1965. Hydraulic conductivity of peats. Soil Sci. 100: 227-231.

1969. Physical properties of peats as related to degree of decomposition. Soil Sci. Soc. Amer. Proc. 33: 606-609.

Carlston, C. W. 1964. Tritium-hydrologic research: some results of the U. S. Geological Survey research program. Science 143: 804-806.

Farnham, R. S., and D. N. Grubich. 1966. Peat resources of Minnesota. Report of inventory no. 3, Red Lake Bog, Beltrami County. Office of Iron Range Resources and Rehabilitation, St. Paul, Minn. 24 p.

Finney, H. R., and R. S. Farnham. 1968. Proc. 3rd Int. Peat Congress, Quebec City, Canada, August 1968, pp. 102-108.

Forsgren, B. 1966. Tritium determinations in the study of palsa formation. Geogr. Ann. 48A: 102-110. $\rightarrow$ Heinselman, M. D. 1963. Forest sites, bog processes, and peatland types in the Glacial Lake Agassiz Region, Minnesota. Ecol. Monogr. 33: 327-374.

Hofstetter, R. H. 1969. Floristic and ecological studies of Minnesota wetlands. Ph.D. Thesis. Univ. Minnesota, Minneapolis, Minn. Part A, 224 p.

International Atomic Energy Agency (Vienna). 1967. Tritium and other environmental isotopes in the hydrological cycle. Tech. Rep. Ser., No. 73.83 p.

Livingstone, D. A. 1955. A light weight piston sampler for lake sediments. Ecology 36: 137-139.

Malmström, C. 1923. Degerö Stormyr. Medd. Statens Skogsförsöksanst. 20: 1-206.

Mortimer, C. H. 1942. Exchange of dissolved substances between mud and water in lakes. J. Ecol. 30: 147201.

Odén, S. 1964. C-14 och Tritium isotopernas förekomst över Skandinavien under senare år med tillämpning inom marklära och hydrologi. Grundförbättring 17: $122-142$. 